\title{
DERECHO Y POLÍTICAS AMBIENTALES EN LAS ISLAS BALEARES
}

\section{DRET I POLÍTIQUES AMBIENTALS A LES ILLES BALEARS}

JOSEP MANUEL GÓMEZ GONZÁLEZ

Jefe de Servicio Jurídico de Ordenación del Territorio

Departamento de Territorio e Infraestructuras. Consejo Insular de Mallorca 
Sumario: 1. Introducción. 2. Actividad legislativa y normativa. 2.1. Aprobado el proyecto de ley de cambio climático y transición energética. 2.2. Aprobado el Decreto sobre la conservación de la Posidonia oceanica. 2.3. Aprobada la revisión anticipada del Plan Hidrológico de las Islas Baleares. 3. Política de residuos. 3.1. Aprobación inicial del Plan Director Sectorial de Residuos no Peligrosos de Mallorca. 3.2. Previsiones de un nuevo decreto sobre gestión de residuos sanitarios. 4. Gestión de espacios naturales. 4.1. Ampliación del Parque Nacional del Archipiélago de Cabrera. 4.2. Estado de tramitación de diferentes instrumentos de ordenación y de gestión de los espacios naturales de las Baleares. 5. Otras políticas ambientales. 5.1. Control ambiental del riego de campos de golf. 5.2. Recursos marinos.

\section{INTRODUCCIÓN}

Este semestre se ha caracterizado por una actividad que recoge buena parte del trabajo programático derivado de los pactos de gobernabilidad de las elecciones de 2015. Algunas de las Leyes con más carga política están llegando al Parlamento en la recta final de la legislatura, después de largos procesos de elaboración y participación. Anteriormente, las sucesivas reformas de la legislación turística y la nueva ley de urbanismo, junto con otras propuestas singulares, como la ley de declaración del Parque Natural de Es Trenc - Es Salobrar, habían copado las iniciativas con incidencia territorial y ambiental. Ahora queda pendiente la tramitación final de la ley de residuos, de la ley de caminos públicos y de la ley de cambio climático y transición energética, como hitos programáticos de clara incidencia medioambiental.

En este número revisaremos la propuesta de Ley de cambio climático y transición energética que se ha aprobado como proyecto de ley y ha iniciado la correspondiente tramitación parlamentaria. También analizaremos los primeros efectos de la aprobación e implementación del necesario y pionero Decreto sobre la conservación de la Posidonia oceanica que entró en vigor el pasado verano y que plantea unos grandes retos de gestión e incorporación de medios materiales, económicos y personales con el fin de hacerlo plenamente efectivo.

Por otra parte, los sucesivos incumplimientos del Estado en materia de transposición de la normativa europea de agua y de residuos, obliga también a revisar anticipadamente el Plan Hidrológico de las Islas Baleares y a tramitar y aprobar un nuevo Plan Director Sectorial de Residuos no Peligrosos de Mallorca, dos materias de gran complejidad técnica y con enormes repercusiones sociales y económicas. Ambos documentos se encuentran en un adelantado estado de 
tramitación. En la misma línea se trabaja en un nuevo decreto sobre gestión de residuos sanitarios.

Finalmente realizaremos una revisión sucinta en materia de gestión de espacios naturales, con la relevante propuesta de ampliación del Parque Nacional del Archipiélago de Cabrera y el análisis del estado de tramitación de diferentes instrumentos de ordenación y de gestión de los espacios naturales de las Baleares. Igualmente comentaremos algunas cuestiones sobre otras políticas ambientales, como el control ambiental del riego de campos de golf y algunas políticas de gestión de los recursos marinos.

\section{ACTIVIDAD LEGISLATIVA Y NORMATIVA}

\subsection{Aprobado el proyecto de ley de cambio climático y transición energética}

El Consejo de Gobierno de la Comunidad Autónoma acordó el día 14 de agosto de 2018, aprobar el proyecto de ley de cambio climático y transición energética y enviarlo al Parlamento de las Islas Baleares para la correspondiente tramitación, de conformidad con lo que prevé el artículo 117 del Reglamento de la cámara autonómica. Al mismo acuerdo, también se aprobaba el plande actuación inicial, el estudio económico y financiero y el presupuesto correspondiente al primer ejercicio del Instituto Balear de la Energía. El Boletín Oficial del Parlamento de las Islas Baleares, publicó la documentación correspondiente, que incluye el proyecto de ley, el día 14 de septiembre de 2018 (BOPIB $\left.n^{\circ} .156\right)$.

Como ya se afirma en la memoria que acompaña el proyecto de ley, el cambio climático es uno de los principales problemas actuales del planeta. De hecho, su día ya justificó el hecho de conformar uno de los ejes principales de la Conferencia de las Naciones Unidas sobre Medio Ambiente y Desarrollo, dada en Río de Janeiro en junio de 1992. De esta cumbre (Rio 1992) surgió el Convenio de las Naciones Unidas sobre el cambio climático ${ }^{1}$. Igualmente, la

\footnotetext{
${ }^{1}$ Convención Marco sobre el Cambio Climático o Convención Marco de las Naciones Unidas sobre el Cambio Climático, (CMNUCC). En inglés se conoce como United Nations Framework Convention on Climate Change (UNFCCC o FCCC).
} 
firma del convenio comportó el impulso definitivo a los trabajos preliminares realizados por el Grupo Intergubernamental de Expertos sobre el Cambio Climático (GIECC), en inglés Intergovernmental Panel on Climate Change (IPCC), que fue creado el año 1988 por la Organización Meteorológica Mundial (OMM) y el Programa Ambiental de las Naciones Unidas (PNUMA o UNEP) con el objetivo de centrarse en la investigación del comportamiento del cambio climático.

A partir de los cinco informes del Grupo Intergubernamental de Expertos sobre el Cambio Climático y de los estudios de vulnerabilidad ante este cambio elaborados por la Agencia Española de Meteorología (AEMET), surge la necesidad de contribuir a la respuesta global a la problemática. Para combatir los impactos que puede provocar la modificación del clima a escala regional, hay que transitar también hacia una transformación en profundidad del modelo energético con la finalidad de reducir progresivamente la dependencia de los combustibles fósiles y la incorporación de las energías renovables.

El proyecto de ley, se estructura en siete títulos que incluyen noventa y cinco artículos, además de nueve disposiciones adicionales, cuatro disposiciones transitorias, una disposición derogatoria y cinco disposiciones finales; se trata de una ley muy completa que ordena las acciones encaminadas a la mitigación y la adaptación al cambio climático del archipiélago balear en un marco globalizado. Uno de los pilares de la norma es programar la transición a un modelo energético sostenible, descarbonizado y eficiente.

Entre las finalidades de la ley, encontramos que se mencionan: la estabilización y el decrecimiento de la demanda energética, priorizando, en este orden, el ahorro energético, la eficiencia energética y la generación con energías renovables. Igualmente se busca la reducción de la dependencia energética exterior y el avance hacia un escenario con la máxima autosuficiencia y garantía de suministro energético. Ecológicamente es una prioridad la progresiva descarbonización de la economía, así como la implantación progresiva de las energías renovables y la reducción de las emisiones de gases con efecto de invernadero, de acuerdo con los compromisos adquiridos por el Estado español y la Unión Europea y con especial atención al hecho insular. 
La ley también pretende el fomento para la democratización de la energía, entendida como el derecho de la ciudadanía en el acceso a la energía como consumidores y productores, y la responsabilidad de estos como parte activa del sistema. Igualmente se reconoce el derecho a la información y a la formación por parte de las personas usuarias en el ámbito energético para adaptar el consumo y la producción a políticas energéticas sostenibles y eficientes. También se persigue obtener un impacto económico, social y ambiental positivo del sistema energético en los ciudadanos.

Otro grupo de objetivos lo conformarían: El fomento de la gestión inteligente de la demanda de energía con el objetivo de optimizar la utilización de los sistemas energéticos de acuerdo con los objetivos de esta Ley; la planificación y la promoción de la resiliencia y la adaptación de la ciudadanía, de los sectores productivos y de los ecosistemas a los efectos del cambio climático; y el avance cabe en el nuevo modelo medioambiental y energético siguiendo los principios de la transición justa, teniendo en cuenta los intereses de la ciudadanía y de los sectores afectados por esta transición.

Literalmente el proyecto de ley afirma:

"Estos principios son la disponibilidad de energía de acuerdo con las necesidades, la asequibilidad, las garantías procedimentales y el acceso a la justicia, el buen gobierno, la sostenibilidad, la equidad intrageneracional, la equidad intergeneracional y la responsabilidad, en términos complejos de los gobiernos, de las corporaciones, de las generaciones presentes con las futuras y de la sociedad con el ecosistema. En particular, se tienen que tener en cuenta los potenciales impactos laborales de las medidas y la necesidad de evitar la deslocalización de actividades, de lugares de trabajo o de emisiones de las Islas Baleares en otros territorios".

Además de fijar los principios informadores mencionados con relación a las políticas de transición energética y ecológica de la economía, la ley establece la organización administrativa de la competencia y de la gestión en materia de cambio climático, incorporando un Consejo Balear del Clima y un Comité de Expertos para la Transición Energética y el Cambio Climático, además de crear y organizar el Instituto Balear del Clima. 
Por otro lado, se busca implantar una gestión energética transversal en el sector público con la finalidad de racionalizar el consumo energético e incorporar la máxima eficiencia posible, con la designación de los gestores energéticos y la verificación mediante auditorías.

La planificación es otra de las estrategias de la ley, con la finalidad de racionalizar el sistema vigente. Así, se crea el "Plan de Transición Energética y Cambio Climático", entendido como un marco integrado y transversal de ordenación y planificación de objetivos, políticas y acciones que permitan cumplir con las finalidades de la Ley.

El contenido del plan se estructura en una serie de apartados que, a su vez, se despliegan de manera detallada mediante una serie de artículos dentro del título relativo a la planificación. Así, la estructura del plan sería:

“a) El marco estratégico de adaptación.

b) Los objetivos de reducción de emisiones y de los presupuestos de carbono en el marco de la planificación estatal.

c) Los objetivos de ahorro y eficiencia energética y penetración de energías renovables.

d) Las líneas estratégicas de actuación sectorial y territorial de transición energética, y de mitigación y adaptación al cambio climático.

e) El procedimiento para su evaluación, seguimiento y prórroga".

Igualmente se prevén una serie de preceptos destinados a implantar la perspectiva climática, que deberá incorporarse a todas las leyes, las disposiciones normativas, los presupuestos y los programas que se desplieguen dentro del ámbito de la comunidad autónoma.

Otro instrumento que se reconfigura con la ley, es el Plan Director Sectorial Energético, que tiene que ajustarse a los objetivos y determinaciones del señalado Plan de Transición Energética y Cambio Climático e, igualmente, se tiene que adaptar a los contenidos de la ley. Como instrumentos que completan este esquema en cascada, se crean los planes de acción municipales para el clima y la energía sostenible, al amparo de las metodologías desplegadas por la Unión Europea, planes que también tienen que respetar los objetivos del Plan de Transición. 
Finalmente, la evaluación ambiental de planes, programas y proyectos, tendrá que integrar la variable del cambio climático sobre la base de los objetivos del Plan de Transición. En este sentido se habilita a la Comisión de Medio Ambiente de las Islas Baleares para imponer condicionantes dirigidos a reducir emisiones, aumentar el uso de energías renovables o reducir la vulnerabilidad al cambio climático, de manera justificada y de acuerdo con los términos que se establezcan reglamentariamente.

Con respecto a las políticas energéticas, la ley opta por la reducción de las emisiones -tanto difusas como no difusas- y para implantar mecanismos de compensación de estas emisiones. Para eso crea un registro balear de huella de carbono y uno inventario de emisiones de gases con efecto de invernadero. En otro orden de cosas, se apuesta por la eficiencia energética en los medios de producción, en los edificios, en las infraestructuras públicas y en todo un conjunto de instalaciones y aparatos.

Un capítulo se reserva en las energías renovables, su impulso y marco de implantación con carácter general. Igualmente, facilita tanto la creación de instalaciones de generación de renovables para alimentar las redes eléctricas como con respecto al autoconsumo en cualquiera de las modalidades previstas.

La gestión de la demanda, la reducción de la generación de energía eléctrica de origen fósil, la revisión de las políticas de movilidad y de transportes, y las acciones de sensibilización y difusión, completan los objetivos de la ley, que se cierra -como de costumbre- con el régimen disciplinario en materia de cambio climático y energía y las consiguientes medidas sancionadoras.

\subsection{Aprobado el Decreto sobre la conservación de la Posidonia oceanica}

El Consejo de Gobierno de las Islas Baleares aprobó el Decreto 25/2018, de 27 de julio, sobre la conservación de la Posidonia oceanica en las Islas Baleares ${ }^{2}$, con la finalidad de preservar el hábitat y la especie de esta planta que, en el archipiélago, conforma un conjunto de praderas con una extensión de más de $650 \mathrm{~km}^{2}$.

\footnotetext{
${ }^{2}$ Boletín Oficial de las Islas Baleares, núm. 93 de 28 de julio de 2018 (Fascículo 128 - Seco. I. - Pág. 25543 y ss): <http://www.caib.es/eboibfront/pdf/ca/2018/93/1014007>.
} 
La Posidonia oceanica, por lo común conocida en las Islas como en "alga" (a pesar de no serlo), es una fanerógama marina endémica del mar Mediterráneo, de una importancia biológica extraordinaria, que forma extensas praderas en torno a las Islas Baleares. Se trata de la vegetación marina más tendido en fondos litorales, que se puede encontrar en profundidades de entre 0 y $35 \mathrm{~m}$. Esta planta puede llegar a encontrarse en el Parque Nacional Marítimo-terrestre del Archipiélago de Cabrera, en profundidades de hasta $43 \mathrm{~m}$, con ejemplos representativos de una alta calidad de conservación.

Como se señala en el Decreto aprobado, la Posidonia oceanica es considerada hábitat prioritario (1120 - Posidonion oceanicae) según la Directiva 92/43/CEE del Consejo, de 21 de mayo de 1992, relativa a la conservación de los hábitats naturales y de la fauna y flora silvestres (la conocida como Directiva Hábitats). Gracias a esta medida normativa, la Comunidad Autónoma de las Islas Baleares se convierte en pionera en Europa por el hecho de garantizar la conservación de esta planta con disposiciones concretas y de aplicación directa. Es cierto que Baleares es la comunidad española que cuenta con más superficie de praderas de todo el Estado; más concretamente, se le atribuye más del $50 \%$ del total inventariado.

Como muy bien expone el preámbulo de la norma:

"Aunque la Posidonia oceanica está fuertemente protegida como hábitat y especie bajo la legislación europea y básica estatal, la realidad evidente en el litoral de las Islas Baleares hace que este ecosistema esté sometido a una serie de presiones y amenazas que ponen en peligro el buen estado de conservación, hecho avalado por todas las evidencias científicas. Entre las presiones destaca el uso del fondo marino para obras de puertos, los dragados, la pesca de arrastre ilegal, el efecto acumulativo del fondeo de embarcaciones, el vertido de aguas depuradas deficientemente y las salmueras de la desalación o las operaciones de limpieza de playa que implican la retirada de restos muertos. Entre las amenazas, hay que señalar el aumento de la presión demográfica y turística, que se ha intensificado los diez últimos años; la amenaza del cambio climático, que implica una acidificación de mares y océanos; la dispersión de vectores de enfermedad, o la introducción de especies invasoras, entre otros". 
Es objeto del Decreto, garantizar la conservación de la Posidonia oceanica y las comunidades biológicas de las cuales forma parte, mediante la regulación de los usos y las actividades que puedan afectar a la especie y el hábitat, y la promoción de acciones que contribuyan de manera activa al mantenimiento y la consecución de su estado favorable de conservación.

Con esta finalidad prevista, la norma aprobada establece una protección general fundamentada en las previsiones del artículo 57.1 apartado a) de la Ley 42/2007, de 13 de diciembre, del patrimonio natural y de la biodiversidad. De esta manera, al artículo 4.2 y siguientes, el Decreto prohíbe sobre posidonia la pesca de arrastre, las extracciones de áridos, el vertido de materiales dragados y el fondeo incontrolado, pero no los campos de boyas debidamente ordenados y autorizados. Asimismo, también se incluyen dentro de este régimen de limitación las nuevas instalaciones de acuicultura, los emisarios submarinos nuevos y obras nuevas en aquellos casos en que la tramitación ambiental correspondiente determine que puedan tener efectos negativos sobre la posidonia.

La regulación detallada del fondeo de embarcaciones, uno de los puntos más controvertidos del Decreto, se regula en el artículo 7 donde queda prohibido, con carácter general, el fondeo de embarcaciones sobre Posidonia oceanica. Igualmente queda expresamente prohibido el vaciado de sentinas o el vertido de residuos encima de las praderas, incluso en el interior de un campo de boyas.

También se regula el uso que se tiene que hacer de los restos de posidonia (artículo 6). Se prohíbe la retirada, la posesión, el transporte y el uso de restos de posidonia muerta en las playas naturales sin servicios, a excepción de las prácticas destinadas a usos tradicionales y con métodos manuales. En cambio, se puede autorizar en las playas naturales con servicios determinando el método y las zonas de extracción de acuerdo con las características ambientales y geomorfológicas del lugar. Con respecto a las playas urbanas, y por razones socioeconómicas, se permite la retirada siguiendo el manual de buenas prácticas que recoge el mismo Decreto.

Por otra parte, en el artículo 9 del Decreto se crea, con carácter de órgano colegiado, el Comité Posidonia, un comité asesor permanente con representación de las administraciones y los sectores interesados, que se tiene 
que reunir, como mínimo, una vez cada seis meses y tiene atribuidas una serie de funciones consultivas y asesoras para un correcto seguimiento de la aplicación de la normativa en materia de conservación de la Posidonia. Este órgano se nutrirá de las aportaciones que haga la Comunidad Autónoma, otras administraciones, empresas, asociaciones, entre otros, y de las medidas compensatorias de actuaciones que afecten al hábitat y la especie.

El Decreto establece que la Consejería de Medio Ambiente, Agricultura y Pesca tiene que cartografiar las praderas de posidonia existentes en el ámbito de las Islas Baleares, de acuerdo con la mejor información técnica y científica disponible, mediante una orden del consejero. Mientras tanto, la referencia cartográfica a disposición es la que recoge el anexo 3 del Decreto, y el anexo 1 cataloga las praderas de posidonia de alto valor y a regular y establece las zonas. Las delimitaciones cartográficas y su catalogación serán incorporadas a sistemas de información accesibles a los navegantes y al público en general, y en las cartas náuticas.

Además de una serie de previsiones en materia de seguimiento, difusión y sensibilización, el artículo 12 prevé las funciones de vigilancia, de inspección y de control, que queda atribuida a la Administración de la Comunidad Autónoma de las Islas Baleares, y se tienen que ejercer a través de las direcciones generales de Espacios Naturales y Biodiversidad y, si es el caso, de Ordenación del Territorio, así como a través del Servicio de Agentes de Medio Ambiente, en el ámbito en qué se refiere el artículo 1.3 de este Decreto, y sin perjuicio de las funciones que corresponden a la Administración General del Estado, de los consejos insulares y de los municipios de las Islas Baleares, en el ámbito de las competencias propias.

El régimen sancionador se regula en el artículo 13, y se establece por remisión en el artículo 80 de la Ley 42/2007, de 13 de diciembre, del patrimonio natural y de la biodiversidad, y los artículos 50 a 52 de la Ley 5/2005, de 26 de mayo, para la conservación de los espacios de relevancia ambiental (LECO). Con respecto a las infracciones subsumibles en supuestos de la legislación estatal, las multas pueden ir de 100 a 2 millones de euros; con relación a infracciones de la Ley para la conservación de los espacios de relevancia ambiental (LECO) las sanciones pueden ser de 100 euros a 450.000 . 


\subsection{Aprobada la revisión anticipada del Plan Hidrológico de las Islas Baleares}

El Consejo de ministros del día 17 de julio de 2015, a propuesta de la Ministra de Agricultura, Alimentación y Medio Ambiente aprobó el Plan Hidrológico de la Demarcación Hidrográfica de las Islas Baleares, mediante el "Real Decreto 701/2015, de 17 de julio, por el cual se aprueba el Plan Hidrológico de la Demarcación Hidrográfica de las Illes Balears". Desgraciadamente, el plan aprobado incumplía, con relación a la planificación hidrológica derivada de las directivas europeas, el calendario del ciclo de planificación (entre los años 2009 y 2015) así como determinados contenidos. De hecho, es conocido que el Estado español fue incumpliendo el calendario por el hecho de que fue aprobando los planes de las diferentes comunidades autónomas entre los años 2013 y 2014, cuando, en realidad, se tenían que haber aprobado como máximo el año 2009.

En su día, y para evitar una sanción de la UE, se acordó con la Comisión Europea que se cumpliría el plazo previsto del segundo ciclo de planificación (2015-2021). Estos planes tendrían que tomar en consideración, asimismo, las deficiencias detectadas por los técnicos europeos, hecho que el Gobierno anterior no tuvo en cuenta cuando redactó el Plan vigente. A pesar de ello, la inacción sobre el tema a la legislatura 2011-2015, provocó un nuevo retraso en la aprobación de la planificación del nuevo periodo.

Con la finalidad de corregir la situación generada se procedió, apenas iniciado el nuevo mandato, a redactar el documento relativo al ciclo de planificación (20152021) debidamente corregido y enmendado. Así, después del largo y complejo procedimiento de elaboración del documento, con la tramitación ambiental y el informe favorable del Consejo Balear del Agua, el día 21 de septiembre de 2018, el Consejo de Gobierno de la Comunidad Autónoma de las Islas Baleares, aprobó la revisión anticipada del Plan Hidrológico de las Islas Baleares y procedió a enviarlo para su aprobación definitiva por el Consejo de Ministros.

El 16 de octubre de 2018, dentro del trámite previo a la correspondiente aprobación definitiva, el Consejo Nacional del Agua ha informado favorablemente sobre la revisión anticipada del Plan Hidrológico de las Baleares 
y lo ha enviado al Consejo de Ministros a fin de que lo apruebe (al momento de redactarse esta Crónica, todavía no se había adoptado el acuerdo). Una vez el ejecutivo estatal apruebe la revisión del Plan, este entrará en vigor, con lo cual se evita una sanción por las carencias detectadas en el instrumento vigente.

También en su momento, y como podemos leer en la documentación justificativa del nuevo plan, las observaciones de la Comisión Europea hacían referencia explícita al Plan Hidrológico balear, y más en concreto, a la ausencia de actualización del estudio de presiones y de la evaluación de los costes del ciclo integral del agua. Igualmente, se criticaba la falta de seguimiento de las masas de agua superficiales; a la insuficiencia de medidas de reducción de nitratos a las masas subterráneas y de recuperación de costes, y, sobre todo, a la falta de medidas de protección de las masas de agua subterránea objeto de sobreexplotación.

Las novedades que incorpora la revisión anticipada del Plan Hidrológico de las Islas Baleares son: la inclusión de los datos del análisis de la recuperación de los costes de los servicios del agua, el análisis e incorporación de las presiones a todos los tipos de demasiado, que van desde los efectos de las embarcaciones sobre las aguas costeras hasta la sobreexplotación y la contaminación por nitratos en las subterráneas, pasando por los vertidos de las depuradoras en torrentes, entre otros. Además, se ha revisado el estado de las masas de agua subterráneas, con la actualización de los datos de consumos, disponibilidad, calidad y demanda, se han reanudado las tareas de monitorización de las aguas superficiales y se han establecido medidas de gestión de la demanda.

Con el nuevo Plan se adoptan medidas normativas para la protección de las masas de agua subterránea sometidas a sobreexplotación, para evitar la intrusión marina y la contaminación de nitratos. En concreto, la revisión del Plan recoge la prohibición de nuevas autorizaciones y concesiones que afecten masas con sobreexplotación, que son aquellas de las cuales actualmente se extrae más agua de la que entra al acuífero, para todos los usos.

Igualmente, durante la tramitación ambiental se han añadido otras mejoras, como la obligatoriedad de utilizar aguas pluviales o regeneradas a los jardines públicos y de fomentar las especies autóctonas y de bajo requerimiento hídrico, 
además de la previsión de erradicar especies invasoras durante las tareas de limpieza de los torrentes.

\section{POLÍTICA DE RESIDUOS}

\subsection{Aprobación inicial del Plan Director Sectorial de Residuos no Peligrosos de Mallorca}

El Pleno del Consejo de Mallorca, en sesión de día 13 de septiembre de 2018, aprobó inicialmente el Plan Director Sectorial de Residuos no Peligrosos de la isla de Mallorca (PDSRNPMA). ${ }^{3}$ Este Plan es el instrumento de ordenación territorial que tiene por objeto regular el planeamiento, la proyección, la ejecución y la gestión de los sistemas generales de infraestructuras, de equipamientos y de servicios necesarios para la gestión de los residuos no peligrosos (Artículo 11 y siguientes de la Ley 14/2000, de 21 de diciembre, de ordenación territorial de las Islas Baleares). Igualmente, el ámbito material son los residuos no peligrosos (pero no otros tipos de residuos); de hecho, de acuerdo con la Ley 2/2001, de 7 de marzo, de atribución de competencias en los consejos insulares en materia de ordenación del territorio, los residuos peligrosos quedan excluidos expresamente del plan director sectorial. Una de las principales novedades de este plan es que se unifican los actuales dos planes de residuos no peligrosos: el de residuos sólidos urbanos y el de construcción, demolición, voluminosos y neumáticos fuera de uso.

Repasando la memoria y la normativa del PDSRNPM, podemos extraer que el objetivo general del instrumento es regular en el ámbito de la gestión de residuos no peligrosos de Mallorca el planeamiento, la proyección, la ejecución y la gestión de los sistemas generales de infraestructuras. Este objetivo genérico se traslada al plan en la necesidad de cumplir una serie de previsiones programáticas que quedan resumidas así:

- Unificar en un solo plan director todas las tipologías de residuos no peligrosos simplificando así las herramientas de planeamiento y aprovechando las sinergias.

\footnotetext{
3 Publicada la aprobación inicial en el BOIB núm. 116, de 20 de septiembre de 2018: $<$ https://www.conselldemallorca.cat/media/55468/BOIB_CA.pdf $>$.
} 
- Definir la red de infraestructuras para la gestión correcta de los residuos no peligrosos del ámbito de aplicación del plan en base a las necesidades de gestión actual pero también futura en base a los objetivos de gestión de residuos que se apuntan a nivel autonómico, estatal y europeo.

- Establecer una red de tratamiento de residuos orgánicos próxima a la población con el fin de minimizar el impacto y el coste del transporte de estos residuos y acercar el cierre del ciclo de la materia a los lugares de origen.

- Facilitar y potenciar el establecimiento de una red de instalaciones que permitan potenciar la preparación para la reutilización y las recogidas selectivas optimizando los impactos vinculados al transporte y tratamiento.

- Definir la ubicación de la red de infraestructuras maximizando el uso de las reservas actuales definidas para el tratamiento de residuos y reduciendo de esta manera la ocupación de suelo adicional.

- Identificar las mejoras de accesos e infraestructuras auxiliares en las diferentes zonas de tratamiento de residuos.

- Ordenar y proteger el medio ambiente rural y urbano, el patrimonio cultural y el paisaje de acuerdo con el Convenio Europeo del Paisaje y su despliegue estratégico en la isla de Mallorca procurando la integración paisajística y a todos los niveles de los equipamientos e infraestructuras para la prevención y el tratamiento de los residuos en su entorno.

- Definir a través del Estudio de Impacto ambiental elementos de protección para la salud de la población y del medio minimizando los efectos negativos derivados de la red de instalaciones definida.

Con respecto a la unificación de figuras tenemos que, a causa de la evolución de la normativa europea y estatal en el marco de la gestión de residuos no peligrosos y a la evolución de los residuos en el mismo territorio, hay que adecuar los dos instrumentos preexistentes, por una parte, el Plan Director Sectorial para la Gestión de los Residuos Urbanos de la isla de Mallorca, aprobado por el Pleno del Consejo de Mallorca, día 6 de febrero de 2006 (BOIB n. 35, de día 9 de marzo de 2006) y, por otra parte, el Plan Director Sectorial para la Gestión de los Residuos de Construcción-Demolición, Voluminosos y Neumáticos fuera de Uso de la Isla de Mallorca, aprobado definitivamente en el pleno del Consejo Insular 
de Mallorca celebrado día 29 de julio de 2002 (BOIB nº. 141, de día 23 de noviembre de 2002. Ahora, el PDSRNPM en redacción, pretende ser el instrumento sectorial de planificación territorial común y único bajo la denominación o tipología de residuos no peligrosos.

Los principios sobre los cuales se ha elaborado el nuevo plan son los siguientes:

“a) GENERALES

- Principio de protección de la salud humana y del medio ambiente

- Principio de contribución de la lucha contra el cambio climático

- Principio de ciclo de vida y economía circular de los recursos

b) BASE JERÁRQUICA

- Principio de jerarquía de gestión

- Principio de suficiencia

- Principio de proximidad

c) BASE ECONÓMICA

- Principio de responsabilidad ampliada al productor

- Principio de quien contamina paga

- Principio de proporcionalidad del coste de la gestión y de suficiencia económica

d) BASE JURÍDICA Y ADMINISTRATIVA

- Principio de precaución

- Principio de responsabilidad compartida

- Principio de subsidiariedad

- Principio de transparencia y acceso a la información".

Entre los objetivos y retos más importantes del Plan, y que también supone una gran novedad, se encuentra el hecho de afrontar la separación de materia orgánica, implantando la recogida en toda Mallorca en dos años y planificando nuevas infraestructuras de compostaje para poder asumirla.

También se potencia el servicio de los centros de reciclaje y de las estaciones de transferencia con el fin de facilitar y potenciar el establecimiento de una red de instalaciones que permitan potenciar la preparación para la reutilización y las recogidas selectivas minimizando los impactos vinculados al transporte y tratamiento. En el caso de los centros de reciclaje, el plan prevé que todas dispongan de un espacio para la preparación del residuo con la finalidad de su reutilización. 
Para poder llevar a cabo todos estos objetivos se ha planteado una serie de mejoras en las instalaciones de tratamiento. Por una parte, se planifican nuevas instalaciones descentralizadas de Son Reus, para fabricar compuestos de materia orgánica y de otros espacios para el tratado de lodos. $\mathrm{Y}$, por otra parte, se mejorarán y se ampliarán las estaciones de transferencia

El planteamiento que se hace es el de mantener el sistema de gestión insularizada, pero con plantas descentralizadas, de manera que se acerque al máximo el tratamiento, sobre todo de materia orgánica, a los municipios. Además, todas las reformas y nuevas instalaciones se harán con la mejor tecnología disponible en el momento de la obra, cosa que ahora no sucedía porque el PDS anterior especifica la tecnología a utilizar.

Por otra parte, y para dar cobertura al nuevo sistema de separación de envases, el Sistema de Depósito Devolución y Retorno (SDDR), se ha planteado la reserva de suelo para una Planta de lavado de envases, y también se contempla una máquina de recuento para dar apoyo al sistema.

Uno de los grandes beneficios territoriales de este PDSR es el aprovechamiento de todo el suelo que ya estaba reservado al servicio público, reduciendo la ocupación de suelo adicional. Incluso, se desafecta territorio para que se pueda destinar a otros usos. Por otra parte, hay que destacar que el PDSR no se contempla la entrada de residuos de fuera de las islas Baleares.

Todos estos objetivos están encaminados a respetar la jerarquía de residuos y a potenciar un cambio de modelo hacia una economía circular. Dos conceptos encaminados, por otra parte, a seguir las normativas europeas.

\subsection{Previsiones de un nuevo decreto sobre gestión de residuos sanitarios}

El Gobierno de las Islas Baleares ha iniciado la elaboración de un nuevo decreto destinado a adaptar la gestión de residuos sanitarios a la situación actual con nuevas condiciones para almacenarlos y recogerlos. Así, la gestión de los residuos sanitarios se regulará mediante una normativa actualizada y adaptada a las condiciones reales existentes. Se tiene que acordar de que la normativa vigente es del año 1996; es evidente que este marco necesita ser revisado para dar respuesta a las necesidades actuales, especialmente con respecto a las 
condiciones de almacenaje, los plazos y la recogida de residuos. Por eso, la Dirección General de Educación Ambiental, Calidad Ambiental y Residuos de la Consejería de Medio Ambiente, Agricultura y Pesca en colaboración con la Consejería de Salud han redactado el nuevo texto.

Actualmente las Islas Baleares cuentan con muchos más centros que generan residuos sanitarios de lo que hace 22 años y además se ha diversificado la tipología de centros generadores de residuos. Igualmente, en el tiempo transcurrido desde el anterior decreto, que fue pionero en su momento en toda Europa, se han incorporado a la legislación, con carácter básico, varias normas que afectan a los residuos en general y los sanitarios en particular y que se deben tener presentes. Aspectos como los relativos a la Administración electrónica, la planificación o el reparto competencial en el ámbito de las Islas Baleares han hecho necesaria la revisión de la norma todavía vigente.

En el nuevo decreto se han actualizado conceptos, se han incluido dentro del ámbito de aplicación nuevas actividades. Igualmente se ha reorganizado la clasificación de los residuos ajustándose a la Lista europea (LER). Asimismo, el decreto en redacción prevé la aplicación de nuevos criterios técnicos en la gestión con el fin de garantizar una máxima protección de la salud pública y el medio ambiente.

\section{GESTIÓN DE ESPACIOS NATURALES}

\subsection{Ampliación del Parque Nacional del Archipiélago de Cabrera}

Una muy buena noticia para la conservación del archipiélago ha sido el anuncio formalizado por la ministra de Transición Ecológica y la presidenta del Gobierno de las Islas Baleares relativo a la ampliación en 80.000 hectáreas del Parque Nacional de Cabrera, que se convertirá así en la reserva marítimo-terrestre mayor de España después de que el Ministerio haya aceptado la propuesta del Gobierno.

Con el anuncio se adoptó el compromiso de acelerar los trámites de la ampliación del Parque Nacional, que pasará de las 10.000 hectáreas actuales a las 90.712 de la propuesta. Esta ampliación era una aspiración que había quedado bloqueada durante años y que, con el cambio de Gobierno en España con una 
sensibilidad diferente hacia el Medio Ambiente y las Islas Baleares, se ha podido abordar. La ampliación permitirá multiplicar por 9 las dimensiones del Parque Nacional, con el máximo grado de protección y preservar mejor un espacio natural emblemático, que se convertirá en el Parque Marítimo-terrestre mayor de España.

Este proyecto permitirá alojar un gran santuario de cetáceos en el sur del archipiélago, lugar de gran importancia para estas especies, y recoger en su ámbito una serie de especies y hábitats de profundidad que todavía no están representados en ningún espacio protegido autonómico o estatal, como los fondos detríticos y sedimentarios, los bancos de corales profundos, el fondo de Maërl, las comunidades coralígenas, las praderas fanerógamas marinas, las grandes montañas, cuevas, túneles y cañones submarinos, entre otros.

Tanto desde el Gobierno de las Islas Baleares como desde el Ministerio, se valoró muy positivamente el nuevo escenario, después de que el Gobierno de Mariano Rajoy paralizara y bloqueara de forma unilateral un proyecto en el cual se había estado trabajando a lo largo de tres años. El compromiso adoptado con la ampliación permitirá proteger y preservar para futuras generaciones un conjunto de hábitats únicos, que ahora mismo no están incluidos por ningún espacio de la Red de Parques Nacionales.

\subsection{Estado de tramitación de diferentes instrumentos de ordenación y de gestión de los espacios naturales de las Baleares}

Esta legislatura la Consejería de Medio Ambiente, Agricultura y Pesca del Gobierno de las Islas Baleares ha iniciado los trámites de revisión de buena parte de los instrumentos de ordenación de los espacios naturales protegidos del archipiélago, dado que en muchos casos se había superado el periodo de vigencia previsto inicialmente o faltaba la adaptación a normativa sobrevenida.

La última de las acciones emprendidas se ha materializado con el Acuerdo del Consejo de Gobierno de 6 de julio de 2018 por el cual se inicia el procedimiento de elaboración del Plan de Ordenación de los Recursos Naturales de Mondragó, un parque natural del sureste de Mallorca, con un sistema de barrancos, playas y áreas agrícolas de alto valor etnológico que, en 1991, ya habían sido declaradas como Área Natural de Especial de Interés (ANEI). Con el nuevo Plan 
el Parque podrá resolver algunos de los problemas de ordenación que están sufriendo las zonas más sensibles, como los sistemas de dunas contiguos a las playas y las zonas húmedas asociadas a los torrentes.

Por otro lado, el Gobierno de las Islas Baleares ha propuesto ampliar el Parque Natural de la península de Levante creado originariamente con el Decreto 127/2001, de 9 de noviembre, por el cual se declaran el parque natural de la península de Levante y las reservas naturales de Cap Farrutx y Cap Des Freu. Esta ampliación resultaba una tarea pendiente después que a la legislatura 2003-2007, mediante la Ley 10/2003, de 22 de diciembre, de medidas tributarias y administrativas (ley de acompañamiento de los presupuestos) y sin ningún procedimiento amparado en la legislación de espacios naturales, este emblemático espacio natural de la isla de Mallorca fuera recortado drásticamente pasando de las 16.232 hectáreas terrestres originales y las 5.275 hectáreas marinas a las 1.671 hectáreas. Este recorte fue uno más de las realizadas por el gobierno de Jaume Matas, afectando a otros lugares emblemáticos de Mallorca y de Ibiza.

Todo eso se suma a la tramitación del nuevo Plan Rector de Uso y de Gestión (PRUG) del Parque Natural de Sa Dragonera, que se encuentra en la recta final de elaboración y aprobación, y al acuerdo que adoptó el Consejo de Gobierno de la CAIB el 23 de febrero de 2018, por el que se iniciaba el procedimiento de elaboración del Plan de Ordenación de los Recursos Naturales del Parque Natural de S'Albufera de Mallorca, que también se está redactando.

\section{OTRAS POLÍTICAS AMBIENTALES}

\subsection{Control ambiental de la acequia de campos de golf}

Esta legislatura la Dirección General de Recursos Hídricos de la Consejería de Medio Ambiente, Agricultura y Pesca ha expedientado toda una serie de campos de golf de Mallorca con sanciones que suman cerca de un millón de euros. Los expedientes se han incoado en el marco de la campaña de control del uso del agua de los grandes consumidores que ya hace tres años que impulsa la Consejería y en los cuales los agentes de medio ambiente han llevado a cabo diferentes actuaciones de inspección y control para detectar usos fraudulentos 
de consumo de agua, junto con los especialistas de la Dirección General de Recursos Hídricos y con el apoyo del Laboratorio del Agua.

La primera sanción se impuso a un golf del municipio de Andratx, después de localizar un sondeo ilegal de 180 m para la extracción de aguas subterráneas, con una capacidad de extracción de $720 \mathrm{~m}^{3} /$ día, que se destinaba exclusivamente al riego del campo de golf. También se detectó el suministro ilegal de agua subterránea destinada al consumo humano, con un caudal de 173 $\mathrm{m}^{3} /$ día, que igualmente se utilizaba para regar este campo.

En segundo lugar, se ha procedido a sancionar otro golf en el municipio de Felanitx, después de haber constatado la comisión de tres infracciones en materia de dominio público hidráulico: la realización de un sondeo ilegal; la extracción ilegal de agua de dos sondeos, y la utilización del agua subterránea extraída para regar el campo de golf, lo cual supone el incumplimiento de la normativa vigente, que fija que los campos de golf sólo se pueden regar con aguas procedentes de depuradora o desalinizadora.

En tercer lugar, se ha comunicado la propuesta de resolución del expediente sancionador a un campo de golf en el término municipal de Palma, por haber incumplido la concesión por reordenación de captaciones y por haber llevado a cabo, sin autorización administrativa, tres sondeos, dos de los cuales con extracción de agua. En este caso, los agentes de medio ambiente constataron la existencia de tres sondeos, sin autorización, de la cual dos eran mecanizados y sin caudalímetro ni tubo piezométrico. En total, el campo de golf cuenta con nueve sondeos, seis de los cuales tienen una autorización de reordenación de captaciones para usos domésticos y de regadío.

Las perforaciones ilegales y la instalación de mecanismos para la extracción de agua con las proporciones detectadas e investigadas, se considera especialmente grave, dado que la masa de la cual se extrae el agua se califica, en el Plan Hidrológico de las Islas Baleares (PHIB), como en deterioro estructural

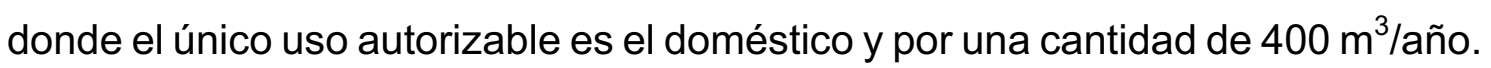
Por lo tanto, es una tipología de masa de agua sometido a autorizaciones muy restringidas y tan sólo para abastecer necesidades de primer orden. Con respecto a la obligación de restituir el dominio público hidráulico, se tienen que 
sellar los sondeos, con la autorización previa de la Dirección General de Recursos Hídricos y en presencia de los agentes de medio ambiente para extender acta de la restitución.

En el marco de esta campaña de control del uso del agua de los grandes consumidores, se investigan cuatro campos de golf más.

\subsection{Recursos marinos}

Finalmente, con respecto a la protección de áreas marinas, en estos momentos se encuentra en información pública el borrador de Proyecto de Decreto por el que se establece la Reserva Marina de la Isla del Aire (Menorca) y se regulan las actividades de extracción de flora y fauna marina y las actividades subacuáticas.

Igualmente, se está trabajando entre el gobierno del Estado, el gobierno de la Comunidad Autónoma y el Consejo Insular de Mallorca, para posibilitar la ampliación del ámbito de protección marina en torno al Parque Natural de Sa Dragonera con la implantación de una nueva reserva marina en aguas exteriores que se añadiría a la Reserva Marina des Freus de Sa Dragonera y en las reservas de la Isla del Toro y las Islas Malgrats. 
Sumari: 1. Introducció. 2. Activitat legislativa i normativa. 2.1. Aprovat el projecte de llei de canvi climàtic i transició energètica. 2.2. Aprovat el Decret sobre la conservació de la Posidonia oceanica. 2.3. Aprovada la revisió anticipada del Pla Hidrològic de les Illes Balears. 3. Política de residus. 3.1. Aprovació inicial del Pla Director Sectorial de Residus no Perillosos de Mallorca. 3.2. Previsions d'un nou decret sobre gestió de residus sanitaris. 4. Gestió d'espais naturals. 4.1. Ampliació del Parc Nacional de l'Arxipèlag de Cabrera. 4.2. Estat de tramitació de diferents instruments d'ordenació $i$ de gestió dels espais naturals de les Balears. 5. Altres polítiques ambientals. 5.1. Control ambiental del reg de camps de golf. 5.2. Recursos marins.

\section{INTRODUCCIÓ}

Aquest semestre s'ha caracteritzat per una activitat que recull bona part de la feina programàtica derivada dels pactes de governabilitat de les eleccions de 2015. Algunes de les Lleis amb més càrrega política estan arribant al Parlament en la recta final de la legislatura, després de llargs processos d'elaboració i participació. Anteriorment, les successives reformes de la legislació turística i la nova llei d'urbanisme, juntament amb altres propostes singulars, com ara la llei de declaració del Parc Natural d'Es Trenc - Es Salobrar, havien copat les iniciatives amb incidència territorial i ambiental. Ara queda pendent la tramitació final de la llei de residus, de la llei de camins públics i de la llei de canvi climàtic i transició energètica, com a fites programàtiques de clara incidència mediambiental.

En aquest número revisarem la proposta de Llei de canvi climàtic i transició energètica que s'ha aprovat com a projecte de llei i ha iniciat la corresponent tramitació parlamentària. També analitzarem els primers efectes de l'aprovació $\mathrm{i}$ implementació del necessari i pioner Decret sobre la conservació de la Posidonia oceanica que va entrar en vigor a l'estiu i que planteja uns grans reptes de gestió i incorporació de mitjans materials, econòmics i personals per tal de fer-lo plenament efectiu.

D'una altra banda, els successius incompliments de l'Estat en matèria de transposició de la normativa europea d'aigua i de residus, obliga també a revisar anticipadament el Pla Hidrològic de les Illes Balears i a tramitar i aprovar un nou Pla Director Sectorial de Residus no Perillosos de Mallorca, dues matèries de gran complexitat tècnica $i$ amb enormes repercussions socials $i$ econòmiques. Ambdós documents es troben en un avançat estat de tramitació. En la mateixa línia es treballa en un nou decret sobre gestió de residus sanitaris. 
Finalment farem una revisió succinta en matèria de gestió d'espais naturals, amb la rellevant proposta d'ampliació del Parc Nacional de l'Arxipèlag de Cabrera i l'anàlisi de l'estat de tramitació de diferents instruments d'ordenació i de gestió dels espais naturals de les Balears. Igualment comentarem algunes qüestions sobre altres polítiques ambientals, com ara el control ambiental del reg de camps de golf i algunes polítiques de gestió dels recursos marins.

\section{ACTIVITAT LEGISLATIVA I NORMATIVA}

\subsection{Aprovat el projecte de llei de canvi climàtic i transició energètica}

El Consell de Govern de la Comunitat Autònoma va acordar el dia 14 d'agost de 2018, aprovar el projecte de llei de canvi climàtic i transició energètica i trametreho al Parlament de les Illes Balears per a la corresponent tramitació, de conformitat amb el que preveu l'article 117 del Reglament de la cambra autonòmica. Al mateix acord, també s'aprovava el pla d'actuació inicial, l'estudi econòmic i financer i el pressupost corresponent al primer exercici de l'Institut Balear de l'Energia. El Butlletí Oficial del Parlament de les Illes Balears, va publicar la documentació corresponent, que inclou el projecte de llei, el dia 14 de setembre de 2018 (BOPIB núm. 156).

Com ja s'afirma a la memòria que acompanya el projecte de llei, el canvi climàtic és un dels principals problemes actuals del planeta. De fet el seu dia ja va justificar el fet de conformar un dels eixos principals de la Conferència de les Nacions Unides sobre Medi Ambient i Desenvolupament, feta a Rio de Janeiro el juny de 1992. D’aquesta cimera (Rio 1992) va sorgir el Conveni de les Nacions Unides sobre el canvi climàtic ${ }^{4}$. Igualment, la signatura del conveni va comportar l'impuls definitiu als treballs preliminars realitzats pel Grup Intergovernamental d'Experts sobre el Canvi Climàtic (GIECC), en anglès Intergovernmental Panel on Climate Change (IPCC), que fou creat l'any 1988 per l'Organització Meteorològica Mundial (OMM) i el Programa Ambiental de les Nacions Unides

\footnotetext{
${ }^{4}$ Convenció Marc sobre el Canvi Climàtic o Convenció Marc de les Nacions Unides sobre el Canvi Climàtic,(CMNUCC). En anglès es coneix com United Nations Framework Convention on Climate Change (UNFCCC o FCCC).
} 
(PNUMA o UNEP) amb l'objectiu de centrar-se en la recerca del comportament del canvi climàtic.

A partir dels cinc informes del Grup Intergovernamental d'Experts sobre el Canvi Climàtic i dels estudis de vulnerabilitat davant aquest canvi elaborats per l'Agència Espanyola de Meteorologia (AEMET), sorgeix la necessitat de contribuir a la resposta global a la problemàtica. Per combatre els impactes que pot provocar la modificació del clima a escala regional, cal transitar també cap a una transformació en profunditat del model energètic amb la finalitat de reduir progressivament la dependència dels combustibles fòssils i la incorporació de les energies renovables.

El projecte de llei, s'estructura en set títols que inclouen noranta-cinc articles, a més de nou disposicions addicionals, quatre disposicions transitòries, una disposició derogatòria i cinc disposicions finals; es tracta d'una llei molt completa que ordena les accions encaminades a la mitigació i l'adaptació al canvi climàtic de l'arxipèlag balear en un marc globalitzat. Un dels pilars de la norma és programar la transició a un model energètic sostenible, descarbonitzat i eficient.

Entre les finalitats de la llei, trobem que s'esmenten: l'estabilització i el decreixement de la demanda energètica, prioritzant, en aquest ordre, l'estalvi energètic, l'eficiència energètica i la generació amb energies renovables. Igualment es busca la reducció de la dependència energètica exterior i l'avanç cap a un escenari amb la màxima autosuficiència i garantia de subministrament energètic. Ecològicament n'és una prioritat la progressiva descarbonització de l'economia així com la implantació progressiva de les energies renovables i la reducció de les emissions de gasos amb efecte d'hivernacle, d'acord amb els compromisos adquirits per l'Estat espanyol i la Unió Europea i amb especial atenció al fet insular.

La llei també pretén el foment de la democratització de l'energia, entesa com el dret de la ciutadania a l'accés a l'energia com a consumidors i productors, i la responsabilitat d'aquests com a part activa del sistema. Igualment es reconeix el dret a la informació i a la formació per part de les persones usuàries en l'àmbit energètic per adaptar-ne el consum i la producció a polítiques energètiques 
sostenibles i eficients. També es persegueix obtenir un impacte econòmic, social i ambiental positiu del sistema energètic en els ciutadans.

Un altre grup d'objectius el conformarien: El foment de la gestió intel·ligent de la demanda d'energia amb l'objectiu d'optimitzar la utilització dels sistemes energètics d'acord amb els objectius d'aquesta Llei; la planificació i la promoció de la resiliència i l'adaptació de la ciutadania, dels sectors productius i dels ecosistemes als efectes del canvi climàtic; i l'avanç cap al nou model mediambiental i energètic seguint els principis de la transició justa, tenint en compte els interessos de la ciutadania i dels sectors afectats per aquesta transició.

Literalment el projecte de llei afirma:

“Aquests principis són la disponibilitat d'energia d'acord amb les necessitats, l'assequibilitat, les garanties procedimentals i l'accés a la justícia, el bon govern, la sostenibilitat, l'equitat intrageneracional, l'equitat intergeneracional i la responsabilitat, en termes complexos dels governs, de les corporacions, de les generacions presents amb les futures i de la societat amb l'ecosistema. En particular, s'han de tenir en compte els potencials impactes laborals de les mesures i la necessitat d'evitar la deslocalització d'activitats, de llocs de feina o d'emissions de les Illes Balears a altres territoris".

A més de fixar els principis informadors esmentats amb relació a les polítiques de transició energètica i ecològica de l'economia, la llei estableix l'organització administrativa de la competència i de la gestió en matèria de canvi climàtic, incorporant un Consell Balear del Clima i un Comitè d'Experts per a la Transició Energètica i el Canvi Climàtic, a més de crear i organitzar l'Institut Balear del Clima.

Per un altre costat es busca implantar una gestió energètica transversal al sector públic amb la finalitat de racionalitzar el consum energètic i incorporar la màxima eficiència possible, amb la designació dels gestors energètics i la verificació mitjançant auditories.

La planificació és una altra de les estratègies de la llei, amb la finalitat de racionalitzar el sistema vigent. Així, es crea el "Pla de Transició Energètica i 
Canvi Climàtic", entès com un marc integrat i transversal d'ordenació i planificació d'objectius, polítiques i accions que permetin complir amb les finalitats de la Llei.

El contingut del pla s'estructura en una sèrie d'apartats que, al seu torn, es despleguen de manera detallada mitjançant una sèrie d'articles dins el títol relatiu a la planificació. Així, l'estructura del pla seria:

“a) El marc estratègic d'adaptació.

b) Els objectius de reducció d'emissions i dels pressuposts de carboni en el marc de la planificació estatal.

c) Els objectius d'estalvi i eficiència energètica i penetració d'energies renovables.

d) Les línies estratègiques d'actuació sectorials i territorials de transició energètica, i de mitigació i adaptació al canvi climàtic.

e) El procediment per a la seva avaluació, seguiment i pròrroga".

Igualment es preveuen una sèrie de preceptes destinats a implantar la perspectiva climàtica, que haurà d'incorporar-se a totes les lleis, les disposicions normatives, els pressupostos i els programes que es despleguin dins l'àmbit de la comunitat autònoma.

Un altre instrument que es reconfigura amb la llei, és el Pla Director Sectorial Energètic, que s'ha d'ajustar als objectius i determinacions de l'assenyalat Pla de Transició Energètica i Canvi Climàtic i, igualment, s'ha d'adaptar als continguts de la llei. Com a instruments que completen aquest esquema en cascada, es creen els plans d'acció municipals per al clima i l'energia sostenible, a l'empara de les metodologies desplegades per la Unió Europea, plans que també han de respectar els objectius del Pla de Transició.

Finalment, l'avaluació ambiental de plans, programes i projectes, haurà d'integrar la variable del canvi climàtic sobre la base dels objectius del Pla de Transició. En aquest sentit s'habilita a la Comissió de Medi Ambient de les Illes Balears per a imposar condicionants dirigits a reduir emissions, augmentar l'ús d'energies renovables o reduir la vulnerabilitat al canvi climàtic, de manera justificada $\mathrm{i}$ d'acord amb els termes que s'estableixin reglamentàriament. 
Pel que fa a les polítiques energètiques, la llei opta per la reducció de les emissions -tant difuses com no difuses- i per implantar mecanismes de compensació d'aquestes emissions. Per a això crea un registre balear de petjada de carboni i u inventari d'emissions de gasos amb efecte d'hivernacle. En un altre ordre de coses, s'aposta per l'eficiència energètica en els mitjans de producció, en els edificis, en les infraestructures públiques i en tot un conjunt d'instal-lacions i aparells.

Un capítol es reserva a les energies renovables, el seu impuls i marc d'implantació amb caràcter general. Igualment facilita tant la creació d'instal-lacions de generació de renovables per alimentar les xarxes elèctriques com pel que fa a l'autoconsum en qualsevol de les modalitats previstes.

La gestió de la demanda, la reducció de la generació d'energia elèctrica d'origen fòssil, la revisió de les polítiques de mobilitat i de transports, i les accions de sensibilització i difusió, completen els objectius de la llei, que es tanca-com de costum- amb el règim disciplinari en matèria de canvi climàtic $i$ energia i les consegüents mesures sancionadores.

\subsection{Aprovat el Decret sobre la conservació de la Posidonia oceanica}

El Consell de Govern de les Illes Balears va aprovar el Decret 25/2018, de 27 de juliol, sobre la conservació de la Posidonia oceanica a les Illes Balears ${ }^{5}$, amb la finalitat de preservar l'hàbitat i l'espècie d'aquesta planta que, a l'arxipèlag, conforma un conjunt de praderies amb una extensió de més de $650 \mathrm{~km}^{2}$.

La Posidonia oceanica, comunament coneguda a les Illes com a "alga" (tot i no ser-ho), és una fanerògama marina endèmica de la mar Mediterrània, d'una importància biològica extraordinària, que forma extenses praderies entorn de les Illes Balears. Es tracta de la vegetació marina més estesa en fons litorals, que es pot trobar en profunditats entre 0 i $35 \mathrm{~m}$. Aquesta planta pot arribar a trobarse al Parc Nacional Marítimo-terrestre de l'Arxipèlag de Cabrera, en profunditats de fins a $43 \mathrm{~m}$, amb exemples representatius d'una alta qualitat de conservació.

\footnotetext{
${ }^{5}$ Butlletí Oficial de les Illes Balears núm. 93 de 28 de juliol de 2018 (Fascicle 128 - Sec. I. - Pàg. 25543 i ss): <http://www.caib.es/eboibfront/pdf/ca/2018/93/1014007>.
} 
Com s'assenyala al Decret aprovat, la Posidonia oceanica és considerada hàbitat prioritari (1120 - Posidonion oceanicae) segons la Directiva 92/43/CEE del Consell, de 21 de maig de 1992, relativa a la conservació dels hàbitats naturals i de la fauna i flora silvestres (la coneguda com a Directiva Hàbitats). Gràcies a aquesta mesura normativa, la Comunitat Autònoma de les Illes Balears es converteix en pionera a Europa pel fet de garantir la conservació d'aquesta planta amb disposicions concretes i d'aplicació directa. És cert que Balears és la comunitat espanyola que compta amb més superfície de praderies de tot l'Estat; més concretament, se li atribueix més del $50 \%$ del total inventariat.

Com molt bé exposa el preàmbul de la norma:

\begin{abstract}
"Tot i que la Posidonia oceanica està fortament protegida com a hàbitat i espècie sota la legislació europea i bàsica estatal, la realitat evident al litoral de les Illes Balears fa que aquest ecosistema estigui sotmès a una sèrie de pressions i amenaces que en posen en perill el bon estat de conservació, fet avalat per totes les evidències científiques. Entre les pressions destaca l'ocupació del fons marí per a obres de ports, els dragatges, la pesca d'arrossegament il·legal, l'efecte acumulatiu de l'ancoratge d'embarcacions, l'abocament d'aigües depurades deficientment i les salmorres del dessalatge o les operacions de neteja de platja que impliquen la retirada de restes mortes. Entre les amenaces, cal assenyalar l'augment de la pressió demogràfica i turística, que s'ha intensificat els deu darrers anys; l'amenaça del canvi climàtic, que implica una acidificació de mars i oceans; la dispersió de vectors de malaltia, o la introducció d'espècies invasores, entre d'altres".
\end{abstract}

És objecte del Decret, garantir la conservació de la Posidonia oceanica i les comunitats biològiques de les quals forma part, mitjançant la regulació dels usos i les activitats que puguin afectar l'espècie i l'hàbitat, i la promoció d'accions que contribueixin de manera activa al manteniment i la consecució del seu estat favorable de conservació.

Amb aquesta finalitat prevista, la norma aprovada estableix una protecció general fonamentada en les previsions de l'article 57.1 apartat a) de la Llei 42/2007, de 13 de desembre, del patrimoni natural i de la biodiversitat. D'aquesta manera, a l'article 4.2 i següents, el Decret prohibeix sobre posidònia la pesca d'arrossegament, les extraccions d'àrids, l'abocament de materials dragats i 
l'ancoratge incontrolat, però no els camps de boies degudament ordenats i autoritzats. Així mateix, també s'inclouen dins aquest règim de limitació les noves instal-lacions d'aqüicultura, els emissaris submarins nous i obres noves en aquells casos en què la tramitació ambiental corresponent determini que puguin tenir efectes negatius sobre la posidònia.

La regulació detallada de l'ancoratge d'embarcacions, un dels punts més controvertits del Decret, es regula en l'article 7 o queda prohibit, amb caràcter general, l'ancoratge d'embarcacions sobre Posidonia oceanica. Igualment queda expressament prohibit el buidatge de sentines o l'abocament de residus damunt les praderies, fins i tot a l'interior d'un camp de boies.

També es regula l'ús que s'ha de fer de les restes de posidònia (art. 6). Es prohibeix la retirada, la possessió, el transport i l'ús de restes de posidònia morta a les platges naturals sense serveis, a excepció de les pràctiques destinades a usos tradicionals i amb mètodes manuals. En canvi, es pot autoritzar a les platges naturals amb serveis determinant-ne el mètode i les zones d'extracció d'acord amb les característiques ambientals i geomorfològiques del lloc. Pel que fa a les platges urbanes, i per raons socioeconòmiques, se'n permet la retirada seguint el manual de bones pràctiques que recull el mateix Decret.

D'altra banda, a l'article 9 del Decret es crea, amb caràcter d'òrgan col·legiat, el Comitè Posidònia, un comitè assessor permanent amb representació de les administracions i els sectors interessats, que s'ha de reunir, com a mínim, un cop cada sis mesos i té atribuïdes una sèrie de funcions consultives i assessores per a un correcte seguiment de l'aplicació de la normativa en matèria de conservació de la Posidonia. Aquest òrgan es nodrirà de les aportacions que hi faci la Comunitat Autònoma, altres administracions, empreses, associacions, entre d'altres, i de les mesures compensatòries d'actuacions que afectin l'hàbitat i l'espècie.

El Decret estableix que la Conselleria de Medi Ambient, Agricultura i Pesca ha de cartografiar les praderies de posidònia existents en l'àmbit de les Illes Balears, d'acord amb la millor informació tècnica i científica disponible, mitjançant una ordre del conseller. Mentrestant, la referència cartogràfica a disposició és la que recull l'annex 3 del Decret, i l'annex 1 cataloga les praderies de posidònia d'alt 
valor i a regular i n'estableix les zones. Les delimitacions cartogràfiques i la seva catalogació seran incorporades a sistemes d'informació accessibles als navegants i al públic en general, i a les cartes nàutiques.

A més d'una sèrie de previsions en matèria de seguiment, difusió i sensibilització, l'article 12 en preveu les funcions de vigilància, d'inspecció i de control, que queda atribuïda a l'Administració de la Comunitat Autònoma de les Illes Balears, i s'han d'exercir a través de les direccions generals d'Espais Naturals i Biodiversitat i, si és el cas, d'Ordenació del Territori, així com a través del Servei d'Agents de Medi Ambient, en l'àmbit a què es refereix l'article 1.3 d'aquest Decret, i sense perjudici de les funcions que corresponen a l'Administració General de l'Estat, dels consells insulars i dels municipis de les Illes Balears, en l'àmbit de les competències pròpies.

El règim sancionador es regula en l'article 13, i s'estableix per remissió a l'article 80 de la Llei 42/2007, de 13 de desembre, del patrimoni natural i de la biodiversitat, i els articles 50 a 52 de la Llei 5/2005, de 26 de maig, per a la conservació dels espais de rellevància ambiental (LECO). Pel que fa a les infraccions subsumibles en supòsits de la legislació estatal, les multes poden anar de 100 a 2 milions d'euros; amb relació a infraccions de la Llei per a la conservació dels espais de rellevància ambiental (LECO) les sancions poden ser de 100 euros a 450.000 .

\subsection{Aprovada la revisió anticipada del Pla Hidrològic de les Illes Balears}

El Consell de ministres del dia 17 de juliol de 2015, a proposta de la Ministra d'Agricultura, Alimentació i Medi Ambient va aprovar el Pla Hidrològic de la Demarcació Hidrogràfica de les Illes Balears, mitjançant el "Real Decreto 701/2015, de 17 de julio, por el que se aprueba el Plan Hidrológico de la Demarcación Hidrográfica de las Illes Balears". Malauradament, el pla aprovat incomplia, amb relació a la planificació hidrològica derivada de les directives europees, el calendari del cicle de planificació (entre els anys 2009 i 2015) així com determinats continguts. De fet és conegut que l'Estat espanyol va anar incomplint el calendari pel fet que va anar aprovant els plans de les diferents comunitats autònomes entre els anys 2013 i 2014, quan, en realitat, s'havien d'haver aprovat com a tard l'any 2009. 
Al seu dia, i per evitar una sanció de la UE, es va acordar amb la Comissió Europea que es compliria el termini previst del segon cicle de planificació (20152021). Aquests plans haurien de prendre en consideració, així mateix, les deficiències detectades pels tècnics europeus, fet que el Govern anterior no va tenir en compte quan va redactar el Pla vigent. Amb tot, la inacció sobre el tema a la legislatura 2011-2015, va provocar un nou retard en l'aprovació de la planificació del nou període.

Amb la finalitat de corregir la situació generada es va procedir, tot just iniciat el nou mandat, a redactar el document relatiu al cicle de planificació (2015-2021) degudament corregit i esmenat. Així, després del llarg i complex procediment d'elaboració del document, amb la tramitació ambiental i l'informe favorable del Consell Balear de l'Aigua, el dia 21 de setembre de 2018, el Consell de Govern de la Comunitat Autònoma de les Illes Balears, va aprovar la revisió anticipada del Pla Hidrològic de les Illes Balears i va procedir a trametre-ho per a la seva aprovació definitiva pel Consell de Ministres.

El 16 d'octubre de 2018, dins el tràmit previ a la corresponent aprovació definitiva, el Consell Nacional de l'Aigua ha informat favorablement sobre la revisió anticipada del Pla Hidrològic de les Balears i l'ha enviat al Consell de Ministres per tal que l'aprovi (al moment de redactar-se aquesta Crònica, encara no s'havia adoptat l'acord). Un cop l'executiu estatal aprovi la revisió del Pla, aquest entrarà en vigor, amb la qual cosa s'evita una sanció per les mancances detectades en el instrumento vigent.

També al seu moment, i com podem llegir a la documentació justificativa del nou pla, les observacions de la Comissió Europea feien referència explícita al Pla Hidrològic balear, i més en concret, a l'absència d'actualització de l'estudi de pressions i de l'avaluació dels costs del cicle integral de l'aigua. Igualment, es criticava la manca de seguiment de les masses d'aigua superficials; a la insuficiència de mesures de reducció de nitrats a les masses subterrànies i de recuperació de costs, i, sobretot, a la manca de mesures de protecció de les masses d'aigua subterrània objecte de sobreexplotació.

Les novetats que incorpora la revisió anticipada del Pla Hidrològic de les Illes Balears són: la inclusió de les dades de l'anàlisi de la recuperació dels costs dels 
serveis de l'aigua, l'anàlisi i incorporació de les pressions a tots els tipus de massa, que van des dels efectes de les embarcacions sobre les aigües costaneres fins a la sobreexplotació i la contaminació per nitrats a les subterrànies, passant pels abocaments de les depuradores a torrents, entre d'altres. A més s'ha revisat l'estat de les masses d'aigua subterrànies, amb l'actualització de les dades de consums, disponibilitat, qualitat i demanda, s'han reprès les tasques de monitoratge de les aigües superficials i s'han establert mesures de gestió de la demanda.

Amb el nou Pla s'adopten mesures normatives per a la protecció de les masses d'aigua subterrània sotmeses a sobreexplotació, per evitar la intrusió marina i la contaminació de nitrats. En concret, la revisió del Pla recull la prohibició de noves autoritzacions i concessions que afectin masses amb sobreexplotació, que són aquelles de les quals actualment se n'extreu més aigua de la que entra a l'aqüífer, per a tots els usos.

Igualment, durant la tramitació ambiental s'hi han afegit altres millores, com l'obligatorietat d'emprar aigües pluvials o regenerades als jardins públics i de fomentar les espècies autòctones i de baix requeriment hídric, a més de la previsió d'eradicar espècies invasores durant les tasques de neteja dels torrents.

\section{POLÍTICA DE RESIDUS}

\subsection{Aprovació inicial del Pla Director Sectorial de Residus no Perillosos de Mallorca}

El Ple del Consell de Mallorca, en sessió de dia 13 de setembre de 2018, va aprovar inicialment el Pla Director Sectorial de Residus no Perillosos de l'illa de Mallorca (PDSRNPMA). ${ }^{6}$ Aquest Pla és l'instrument d'ordenació territorial que té per objecte regular el planejament, la projecció, l'execució i la gestió dels sistemes generals d'infraestructures, d'equipaments i de serveis necessaris per a la gestió dels residus no perillosos (article 11 i següents de la Llei 14/2000, de 21 de desembre, d'ordenació territorial de les Illes Balears). Igualment, l'àmbit material són els residus no perillosos (però no altres tipus de residus); de fet,

\footnotetext{
6 Publicada l'aprovació inicial en el BOIB núm. 116, de 20 de setembre de 2018: $<$ https://www.conselldemallorca.cat/media/55468/BOIB_CA.pdf $>$.
} 
d'acord amb la Llei 2/2001, de 7 de març, d'atribució de competències als consells insulars en matèria d'ordenació del territori, els residus perillosos queden exclosos expressament del pla director sectorial. Una de les principals novetats d'aquest pla és que s'unifiquen els actuals dos plans de residus no perillosos: el de residus sòlids urbans i el de construcció, demolició, voluminosos i pneumàtics fora d'ús.

Resseguint la memòria i la normativa del PDSRNPM, podem extreure que l'objectiu general de l'instrument és regular en l'àmbit de la gestió de residus no perillosos de Mallorca el planejament, la projecció, l'execució i la gestió dels sistemes generals d'infraestructures. Aquest objectiu genèric es trasllada al pla en la necessitat d'acomplir una sèrie de previsions programàtiques que queden resumides així:

- Unificar en un sol pla director totes les tipologies de residus no perillosos simplificant així les eines de planejament i aprofitant les sinèrgies.

- Definir la xarxa d'infraestructures per a la gestió correcte dels residus no perillosos de l'àmbit d'aplicació del pla en base a les necessitats de gestió actual però també futura en base als objectius de gestió de residus que s'apunten a nivell autonòmic, estatal i europeu.

- Establir una xarxa de tractament de residus orgànics propera a la població per tal de minimitzar l'impacte i el cost del transport d'aquests residus i apropar el tancament del cicle de la matèria als llocs d'origen.

- Facilitar i potenciar l'establiment d'una xarxa d'instal-lacions que permetin potenciar la preparació per a la reutilització i les recollides selectives optimitzant els impactes vinculats al transport i tractament.

- Definir la ubicació de la xarxa d'infraestructures maximitzant l'ús de les reserves actuals definides per al tractament de residus i reduint d'aquesta manera l'ocupació de sòl addicional.

- Identificar les millores d'accessos i infraestructures auxiliars a les diferents zones de tractament de residus.

- Ordenar i protegir el medi ambient rural i urbà, el patrimoni cultural i el paisatge d'acord amb el Conveni Europeu del Paisatge i el seu desplegament estratègic a l'illa de Mallorca procurant la integració paisatgística i a tots els nivells dels equipaments i infraestructures per a la prevenció i el tractament dels residus en el seu entorn. 
- Definir a través de l'Estudi d'Impacte ambiental elements de protecció per a la salut de la població i del medi minimitzant els efectes negatius derivats de la xarxa d'instal-lacions definida.

Pel que fa a la unificació de figures tenim que, a causa de l'evolució de la normativa europea i estatal en el marc de la gestió de residus no perillosos i a l'evolució dels residus en el mateix territori, cal adequar els dos instruments preexistents, d'una banda el Pla Director Sectorial per a la Gestió dels Residus Urbans de l'illa de Mallorca, aprovat pel Ple del Consell de Mallorca, dia 6 de febrer de 2006 (BOIB núm. 35, de dia 9 de març de 2006) i d'una altra banda, el Pla Director Sectorial per a la Gestió dels Residus de Construcció-Demolició, Voluminosos i Pneumàtics fora d'Ús de l'Illa de Mallorca, aprovat definitivament en el ple del Consell Insular de Mallorca celebrat dia 29 de juliol de 2002 (BOIB núm. 141, de dia 23 de novembre de 2002. Ara, el PDSRNPM en redacció, pretén ser l'instrument sectorial de planificació territorial comú i únic sota la denominació o tipologia de residus no perillosos.

Els principis sobre els quals s'ha elaborat el nou pla són els següents:

“a) GENERALS

- Principi de protecció de la salut humana i del medi ambient

- Principi de contribució de la lluita contra el canvi climàtic

- Principi de cicle de vida i economia circular dels recursos

b) BASE JERÀRQUICA

- Principi de jerarquia de gestió

- Principi de suficiència

- Principi de proximitat

c) BASE ECONÒMICA

- Principi de responsabilitat ampliada al productor

- Principi de qui contamina paga

- Principi de proporcionalitat del cost de la gestió i de suficiència econòmica

d) BASE JURÍDICA I ADMINISTRATIVA

- Principi de precaució

- Principi de responsabilitat compartida

- Principi de subsidiarietat

- Principi de transparència i accés a la informació" 
Entre els objectius i reptes més importants del Pla, i que també suposa una gran novetat, trobem el fet d'afrontar la separació de matèria orgànica, implantant la recollida a tota Mallorca en dos anys i planificant noves infraestructures de compostatge per poder assumir-la.

També es potencia el servei de les deixalleries i de les estacions de transferència per tal de facilitar i potenciar l'establiment d'una xarxa d'instal-lacions que permetin potenciar la preparació per a la reutilització i les recollides selectives minimitzant els impactes vinculats al transport i tractament. En el cas de les deixalleries, el pla preveu que totes disposin d'un espai per la preparació del residu amb la finalitat de la seva reutilització.

Per poder dur a terme tots aquests objectius s'ha plantejat un seguit de millores a les instal-lacions de tractament. Per una banda, es planifiquen noves instal-lacions descentralitzades de Son Reus, per fer compost de matèria orgànica i d'altres espais pel compost de llots. I per altra banda, es milloraran i s'ampliaran les estacions de transferència

El plantejament que es fa és el de mantenir el sistema de gestió insularitzada però amb plantes descentralitzades, de manera que s'apropi al màxim el tractament, sobretot de matèria orgànica, als municipis. A més a més, totes les reformes i noves instal-lacions es faran amb la millor tecnologia disponible en el moment de l'obra, cosa que ara no succeïa perquè el PDS anterior especifica la tecnologia a utilitzar.

D'altra banda, i per donar cobertura al nou sistema de separació d'envasos, el Sistema de Dipòsit Devolució i Retorn (SDDR), s'ha plantejat la reserva de sòl per a una Planta de rentatge d'envasos, i també es contempla una màquina de recompte per donar suport al sistema.

Un dels grans beneficis territorials d'aquest PDSR és l'aprofitament de tot el sòl que ja estava reservat pel servei públic, reduint l'ocupació de sòl addicional. Fins i tot, es desafecta territori perquè es puguin fer altres usos. Per altra banda, cal destacar que el PDSR no es contempla l'entrada de residus de fora de les illes Balears. 
Tots aquests objectius estan encaminats a respectar la jerarquia de residus i a potenciar un canvi de model cap a una economia circular. Dos conceptes encaminats, per altra banda, a seguir les normatives europees.

\subsection{Previsions d'un nou decret sobre gestió de residus sanitaris}

El Govern de les Illes Balears ha iniciat l'elaboració d'un nou decret adreçat a adaptar la gestió de residus sanitaris a la situació actual amb noves condicions per emmagatzemar-los i recollir-los. Així, la gestió dels residus sanitaris es regularà per una normativa actualitzada i adaptada a les condicions reals existents. S'ha de recordar que la normativa vigent és de l'any 1996; és evident que aquest marc necessita ser revisat per donar resposta a les necessitats actuals, especialment pel que fa a les condicions d'emmagatzematge, els terminis i la recollida de residus. Per això, la Direcció General d’Educació Ambiental, Qualitat Ambiental i Residus de la Conselleria de Medi Ambient, Agricultura i Pesca en col·laboració amb la Conselleria de Salut han redactat el nou text.

Actualment les Illes Balears compten amb molts més centres que generen residus sanitaris que fa 22 anys i a més s'ha diversificat la tipologia de centres generadors de residus. Igualment, en el temps transcorregut des de l'anterior decret, que va ser pioner en el seu moment a tota Europa, s'han incorporat a la legislació, amb caràcter bàsic, diverses normes que afecten els residus en general i els sanitaris en particular i que s'han de tenir presents. Aspectes com els relatius a l'Administració electrònica, la planificació o el repartiment competencial en l'àmbit de les Illes Balears han fet necessària la revisió de la norma encara vigent.

En el nou decret s'han actualitzat conceptes i s'han inclòs dins l'àmbit d'aplicació de la norma noves activitats. Igualment, s'ha reorganitzat la classificació dels residus ajustant-se a la Llista europea (LER). Així mateix, el decret en redacció preveu l'aplicació de nous criteris tècnics en la gestió per tal de garantir una màxima protecció de la salut pública i el medi ambient.

\section{GESTIÓ D’ESPAIS NATURALS}




\subsection{Ampliació del Parc Nacional de l'Arxipèlag de Cabrera}

Una molt bona notícia per a la conservació de l'arxipèlag ha estat l'anunci formalitzat per la ministra de Transició Ecològica i la presidenta del Govern de les Illes Balears relatiu a l'ampliació en 80.000 hectàrees del Parc Nacional de Cabrera, que es convertirà així en la reserva marítimo-terrestre més gran d'Espanya després que el Ministeri hagi acceptat la proposta del Govern.

Amb l'anunci es va adoptar el compromís d'accelerar els tràmits de l'ampliació del Parc Nacional, que passarà de les 10.000 hectàrees actuals a les 90.712 de la proposta. Aquesta ampliació era una aspiració que havia quedat bloquejada durant anys i que amb el canvi de Govern a Espanya amb una sensibilitat diferent envers el Medi Ambient i les Illes Balears, s'ha pogut abordar. L'ampliació permetrà multiplicar per 9 les dimensions del Parc Nacional, amb el màxim grau de protecció i preservar millor un espai natural emblemàtic, que es convertirà en el Parc Marítimo-terrestre més gran d'Espanya.

Aquest projecte permetrà allotjar un gran santuari de cetacis al sud de l'arxipèlag, lloc de gran importància per a aquestes espècies, i recollir en el seu àmbit una sèrie d'espècies i hàbitats de profunditat que encara no estan representats en cap espai protegit autonòmic o estatal, com els fons detrítics i sedimentaris, els bancs de coralls profunds, el fons de Maërl, les comunitats coral·lígenes, les prades fanerògames marines, les grans muntanyes, coves, túnels i canons submarins, entre altres.

Tant des del Govern de les Illes Balears com des del Ministeri, es va valorar molt positivament el nou escenari, després que el Govern de Mariano Rajoy paralitzés i bloquegés de forma unilateral un projecte en el qual s'havia estat treballant al llarg de tres anys. El compromís adoptat amb l'ampliació permetrà protegir i preservar per a futures generacions un conjunt d'hàbitats únics, que ara mateix no estan inclosos per cap espai de la Xarxa de Parcs Nacionals.

\subsection{Estat de tramitació de diferents instruments d'ordenació i de gestió dels espais naturals de les Balears}

Aquesta legislatura la Conselleria de Medi Ambient, Agricultura i Pesca del Govern de les Illes Balears ha iniciat els tràmits de revisió de bona part dels 
instruments d'ordenació dels espais naturals protegits de l'arxipèlag, atès que en molts casos s'havia superat el període de vigència previst inicialment o mancava l'adaptació a la normativa sobrevinguda.

La darrera de les accions empreses s'ha materialitzat amb l'Acord del Consell de Govern de 6 de juliol de 2018 pel qual s'inicia el procediment d'elaboració del Pla d'Ordenació dels Recursos Naturals de Mondragó, un parc natural del sud-est de Mallorca, amb un sistema de barrancs, platges i àrees agrícoles d'alt valor etnològic que, el 1991, ja havien estat declarades com Àrea Natural d'Especial d'Interès (ANEI). Amb el nou Pla el Parc podrà resoldre alguns dels problemes d'ordenació que estan patint les zones més sensibles, com ara els sistemes dunars contigus a les platges i les zones humides associades als torrents.

Per un altre costat, el Govern de les Illes Balears ha proposat ampliar el Parc natural de la península de Llevant creat originàriament amb el Decret 127/2001, de 9 de novembre, pel qual es declaren el parc natural de la península de Llevant i les reserves naturals de Cap Farrutx i Cap Des Freu. Aquesta ampliació resultava una tasca pendent després que a la legislatura 2003-2007, mitjançant la Llei 10/2003, de 22 de desembre, de mesures tributàries i administratives (llei d'acompanyament dels pressuposts) i sense cap procediment emparat en la legislació d'espais naturals, aquest emblemàtic espai natural de l'illa de Mallorca fos retallat dràsticament passant de les 16.232 hectàrees terrestres originals i les 5.275 hectàrees marines a les 1.671 hectàrees. Aquesta retallada va ser una més de les realitzades pel govern de Jaume Mates, afectant altres indrets emblemàtics de Mallorca i d'Eivissa.

Tot això se suma a la tramitació del nou Pla Rector d'Ús i de Gestió (PRUG) del Parc Natural de Sa Dragonera, que es troba en la recta final d'elaboració i aprovació, i a l'acord que va adoptar el Consell de Govern de la CAIB el 23 de febrer de 2018, pel qual s'iniciava el procediment d'elaboració del Pla d'Ordenació dels Recursos Naturals del Parc Natural de s'Albufera de Mallorca, que també s'està redactant.

\section{ALTRES POLÍTIQUES AMBIENTALS}




\subsection{Control ambiental del reg de camps de golf}

Aquesta legislatura la Direcció General de Recursos Hídrics de la Conselleria de Medi Ambient, Agricultura i Pesca ha expedientat tot un seguit de camps de golf de Mallorca amb sancions que sumen prop d'un milió d'euros. Els expedients s'han incoat en el marc de la campanya de control de l'ús de l'aigua dels grans consumidors que ja fa tres anys que impulsa la Conselleria i en la qual els agents de medi ambient han dut a terme diferents actuacions d'inspecció i control per detectar usos fraudulents de consum d'aigua, juntament amb els especialistes de la Direcció General de Recursos Hídrics i amb el suport del Laboratori de l'Aigua.

La primera sanció es va imposar a un golf del municipi d'Andratx, després de localitzar-hi un sondeig il·legal de 180 m per a l'extracció d'aigües subterrànies, amb una capacitat d'extracció de $720 \mathrm{~m}^{3} / \mathrm{dia}$, que es destinava exclusivament al reg del camp de golf. També es va detectar el subministrament il·legal d'aigua subterrània destinada a consum humà, amb un cabal de $173 \mathrm{~m}^{3} / \mathrm{dia}$, que igualment s'utilitzava per regar aquest camp.

En segon Iloc, s'ha procedit a sancionar un altre golf al municipi de Felanitx, després d'haver constatat la comissió de tres infraccions en matèria de domini públic hidràulic: la realització d'un sondeig il·legal; l'extracció il·legal d'aigua de dos sondejos, i la utilització de l'aigua subterrània extreta per regar el camp de golf, la qual cosa suposa l'incompliment de la normativa vigent, que fixa que els camps de golf només es poden regar amb aigües procedents de depuradora o dessaladora.

En tercer lloc, s'ha comunicat la proposta de resolució de l'expedient sancionador a un camp de golf al terme municipal de Palma, per haver incomplert la concessió per reordenació de captacions i per haver dut a terme, sense autorització administrativa, tres sondejos, dos dels quals amb extracció d'aigua. En aquest cas, els agents de medi ambient varen constatar l'existència de tres sondejos, sense autorització, dels quals dos eren mecanitzats i sense cabalímetre ni tub piezomètric. En total, el camp de golf compta amb nou sondejos, sis dels quals tenen una autorització de reordenació de captacions per a usos domèstics i de reguiu. 
Les perforacions il·legals i la instal-lació de mecanismes per a l'extracció d'aigua amb les proporcions detectades i investigades, es considera especialment greu, atès que la massa de la qual s'extreu l'aigua es qualifica, en el Pla Hidrològic de les Illes Balears (PHIB), com en deteriorament estructural i l'únic ús autoritzable és el domèstic i per una quantitat de $400 \mathrm{~m}^{3} / a n y$. Per tant, és un tipus de massa d'aigua sotmès a autoritzacions molt restringides i només per abastir necessitats de primer ordre. Pel que fa a l'obligació de restituir el domini públic hidràulic, s'han de segellar els sondejos, amb l'autorització prèvia de la Direcció General de Recursos Hídrics i en presència dels agents de medi ambient per estendre acta de la restitució.

En el marc d'aquesta campanya de control de l'ús de l'aigua dels grans consumidors, s'investiguen quatre camps de golf més.

\subsection{Recursos marins}

Finalment, pel que fa a la protecció d'àrees marines, en aquests moments es troba en informació pública l'esborrany de Projecte de Decret pel qual s'estableix la Reserva Marina de l'Illa de l'Aire (Menorca) i s'hi regulen les activitats d'extracció de flora i fauna marina i les activitats subaquàtiques.

Igualment, s'està treballant entre el govern de l'Estat, el govern de la Comunitat Autònoma i el Consell Insular de Mallorca, per a possibilitar l'ampliació de l'àmbit de protecció marina al voltant del Parc Natural de Sa Dragonera mitjançant la implantació d'una nova reserva marina en aigües exteriors que s'afegiria a la Reserva Marina des Freus de Sa Dragonera i a les reserves de l'llla del Toro i les Illes Malgrats. 